\title{
MULTI-CRITERIA METHOD (WLC) AND GIS MODELING TO ANALYZE SOIL EROSION VULNERABILITY IN CONSTANTINE CITY (ALGERIA)
}

\author{
Filali ABDELWAHHAB ${ }^{*}$ \\ Laboratory LRNAT, University of Batna-2, Algeria, \\ e-mail: abdelwahhabfilali@gmail.com \\ Guellouh SAMI \\ Laboratory LRNAT, University of Batna-2, Algeria, \\ e-mail: guellouhsami@gmail.com \\ Habibi YAHYAOUI \\ Laboratory LRNAT, University of Batna-2, Algeria, \\ e-mail:y.habibi@univ-batna2.dz \\ Bouhata RABAH \\ Laboratory LRNAT, University of Batna-2, Algeria, \\ e-mail: $\underline{m}$ bouhata24@yahoo.fr
}

Citation: Abdelwahhab, F., Sami, G., Yahyaoui, H., \& Rabah, B. (2020). Multi-criteria Method (WLC) and GIS Modeling to Analyze Soil Erosion Vulnerability in Constantine City (Algeria). Analele Universităţii din Oradea, Seria Geografie, 30(2), 141-146. https://doi.org/10.30892/auog.302103-811

\begin{abstract}
Land degradation due to soil erosion constitutes a serious threat in the Mediterranean regions, and particularly in Algeria. The objective of this study is to characterized the vulnerability to soil erosion in Constantine city (county seat of the Wilaya of the same name) using a spatial multi-criteria method. The followed approach focused on interaction of several factors (climate, topography, lithology and land cover) Acting erosive process by means of Weighted Linear Combination (WLC) that facilitated the quantification of the global effect of these factors in fine and objective manner. The results show that more than $50 \%$ of the city's surface is exposed to high vulnerability, which requires the implementation of soil erosion control measures.
\end{abstract}

Key words: Soil erosion, Factors, Vulnerability, Weighted Linear Combination WLC

* $\quad * \quad * \quad * \quad * \quad *$

\section{INTRODUCTION}

Soil erosion is one of the biggest problems in the world, especially in Algeria. It is a serious environmental, agricultural and social problem that affects and threatens vast area. Among the most 
remarkable consequences, we note the declining fertility of agricultural soils, water pollution, and aggravation of the mud flows in the urban area, the siltation of dams and desertification of the natural environment (FAO, 1980, p. 135; Toundoh et al., 2020. Soil erosion is a complex process that physically takes place by the movement of soil particles from a given site (Saini et al., 2015, p. 9-21).

To study this phenomenon, first, it is necessary to know and identify the different factors influencing this process. The effects of these factors must then be superimposed and adequately quantified in order to obtain more accurate final results using a multi-criteria analysis method.

Different approaches exist to guide a multi-criteria decision situation. Each approach focuses on certain aspects. Therefore each has its advantages and disadvantages (Chakhar, 2006. p. 300).

This method of analysis makes it possible to combine several criteria of different nature, in order to obtain a cartographic result indicating more or less suitable areas capable of solving the problem (Balzarini et al., 2011, p. 85).

The erosive process is the result of the combination of several dynamic and interactive factors (climate, topography, lithology and land cover). To quantify the global effect of these factors, we made call to Weighted Linear Combination (WLC).

WLC is a compensatory method; it makes it possible to compensate, on the same cell, a low value, induced by one criterion, by a higher value, induced by another criterion. This method seems relatively intuitive and simple to implement, especially for decision makers, not necessarily experts in GIS (Balzarini et al., 2011, p. 85).

Weighted Linear Combination is one of the widely used MCE methods for land suitability analysis. It involves standardization of the suitability maps, assigning the weights of relative importance to the suitability's maps, and then combining the weights and standardized suitability maps to obtain an overall suitability score (Malczewski, 2004; Bouguerra and Bouanani, 2016).

This method of analysis has been applied and integrated under a GIS to map vulnerability to soil erosion in the territory of Constantine city (county seat of the Wilaya of the same name), located in eastern Algeria, $431 \mathrm{~km}$ east of the capital Algiers (Algeria).

GIS are tools for data management, processing and analysis (Romocea et al., 2018; Herman et al., 2019) but limited as real decision-making tools, especially when several and/or sometimes contradictory criteria and objectives are involved. Over the past decade, many efforts have been made by GIS software developers to make them evolve. Today, spatial decision-making problems present all the characteristics of multi-criteria problems, which mean that this assessment and treatment are becoming unavoidable (Kedowide Mevo Guezo, 2011, p. 138).

\section{STUDY AREA}

Located in eastern Algeria, Constantine city (county seat of the Wilaya of the same name) covers an area of $90.1 \mathrm{~km}^{2}$, between latitudes $36^{\circ} 16^{\prime}$ and $36^{\circ} 28^{\prime}$ North and between longitudes $6^{\circ}$ $31^{\prime}$ and $6^{\circ} 48^{\prime}$ East (figure 1)

\section{MATERIALS AND METHODS}

In this study, we are based on the integration of spatial multi-criteria analysis into a geographic information system (GIS) to be able to superimpose and quantify the global effect of the different factors contributing to the erosive process. Factors involved in this process fall into four domain: topography, soil, land use and climate (Wischmeier and Smith, 1978, p. 58).

Table 1. Priority and code for each factor

\begin{tabular}{|c|c|c|c|}
\hline Facteurs & Priorité & Classes & Code \\
\hline \multirow{4}{*}{ Slope } & \multirow{3}{*}{1} & $0-5 \%$ & 0.25 \\
\cline { 3 - 4 } & \multirow{3}{*}{1} & $5-15 \%$ & 0.5 \\
\cline { 3 - 4 } & & $15-25 \%$ & 0.75 \\
\cline { 2 - 3 } & & $25 \%<$ & 1 \\
\hline
\end{tabular}




\begin{tabular}{|c|c|c|c|}
\hline \multirow{4}{*}{ Rainfall } & \multirow{4}{*}{2} & $520-560 \mathrm{~mm}$ & 0.25 \\
\hline & & $560-600 \mathrm{~mm}$ & 0.5 \\
\hline & & $600-640 \mathrm{~mm}$ & 0.75 \\
\hline & & $640-672 \mathrm{~mm}$ & 1 \\
\hline \multirow{4}{*}{ Lithology } & \multirow{4}{*}{3} & Lithology erosion_resistant & 0.25 \\
\hline & & Lithology averagely_resistant & 0.5 \\
\hline & & Vulnerable lithology & 0.75 \\
\hline & & Highly Vulnerable lithology & 1 \\
\hline \multirow{4}{*}{ Landuse } & \multirow{4}{*}{4} & Urban area & $\begin{array}{l}\text { Zones excluded from the } \\
\text { analysis }\end{array}$ \\
\hline & & Foret & 0.25 \\
\hline & & agricultural land & 0.5 \\
\hline & & Bare ground & 1 \\
\hline
\end{tabular}

The effect of each factor is quantified and transcribed as a map (figure 1). We have also defined four coded classes for each factor to translate their influence on the phenomenon. The table below summarizes the classes and codes assigned to each factor involved in the analysis.
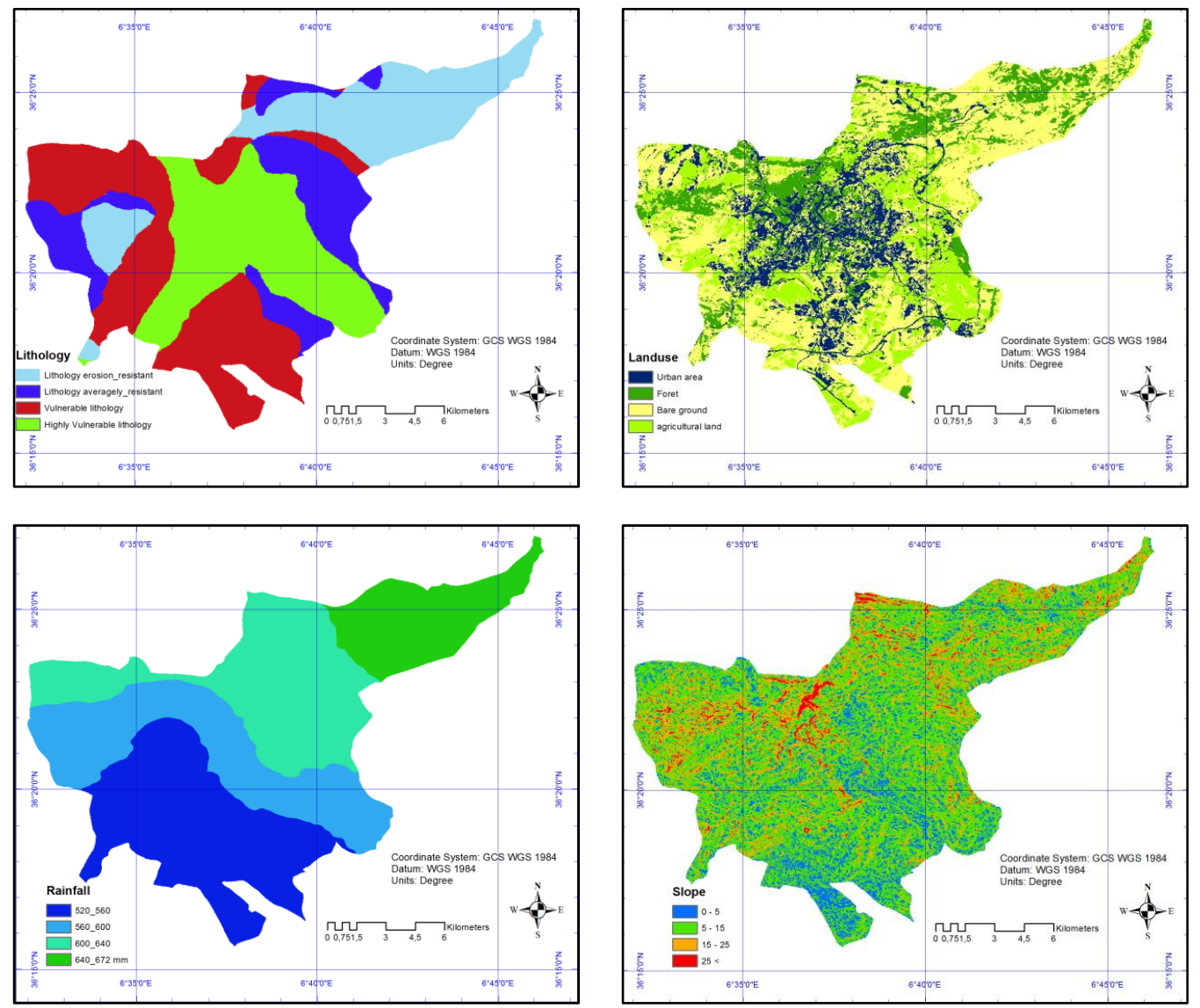

Figure 1. (A) Lithology map (B) Land use map (C) Rainfall map (D) Slope map 
Calculation of the weight for each factor:

Denoting the rank position of the $\mathrm{j}$-th attribute by rj, the most important attribute is ranked first $(\mathrm{rj}=1)$, the second most important attribute ranks second $(\mathrm{rj}=2)$, and so on; the least important attribute is assigned a rank of $r j=n$. Then, the $\mathrm{j}$-th criterion weight can be defined as follows: (Malczewski, 2006. p. 3-65).

$$
\mathbf{w j}=\frac{\mathbf{n}-\mathbf{r} \mathbf{j}+\mathbf{1}}{\sum_{\mathbf{j}=\mathbf{1}}^{\mathbf{n}} \mathbf{n}-\mathbf{r k}+\mathbf{1}} \quad \text { For: } \mathrm{K}=1,2,3 \ldots \ldots \ldots . . . \mathrm{n}
$$

The weights were calculated and inserted into the WLC Tool as a percentage (figure 2). The vulnerability calculation formula is as follows:

The vulnerability $=0.4$ slope +0.3 Rainfall +0.2 lithology +0.1 Landuse

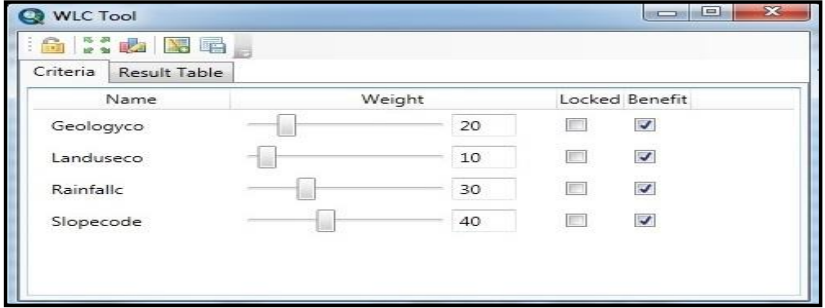

La formule WLC:

Figure 2. Weight for each factor in $\%$

WLC is defined and implemented as follows: For a given set of criteria, WLC is defined as a combination procedure that associates a set of criteria weights with the $i$-th decision alternative (the location or polygon). Where the weights satisfy the following properties: $w 1, w 2, \ldots \ldots, 0 \leq w k \leq 1$ and $\sum_{k=1}^{n} w k=1, k=1,2,3 \ldots \ldots . n$. The weights are multiplied with the criterion values ai 1 , ai $2, \ldots \ldots \ldots$...ain, $i=1,2, \ldots, m$ as in Equation (2) (Steffan, 2016, p. 18).

$$
\mathbf{W L C}(\mathbf{A i})=\sum_{k=1}^{n} W k \cdot V(\alpha i k)
$$

\section{RESULTS AND DISCUSSION}

After determining the priority and weight for each factor, and then integrating into a single information layer using a spatial joint, the global effect can be quantified using the WLC formula under ARC GIS.

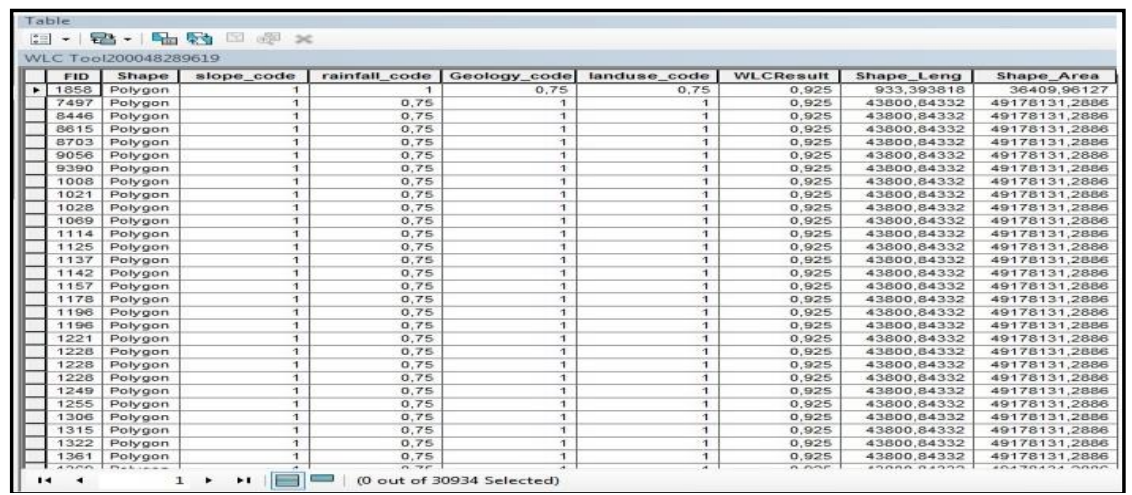

Figure 3. WLC result for each cell 
We have represented the erosion vulnerability in Constantine city under four classes according to the factors global effect as follows:

Table 2. Vulnerability classes

\begin{tabular}{|c|c|c|}
\hline Classes of vulnerability & Global factors effect code & ${\text { Area } \mathbf{~ K m}^{\mathbf{2}}}$ \\
\hline Zero & Urban area & 27.4 \\
\hline Low & $0.06-0.25$ & 2.2 \\
\hline Moderate & $0.25-0.5$ & 8.6 \\
\hline High & $0.5-0.75$ & 28.2 \\
\hline Extreme & $0.75<$ & 23.7 \\
\hline \multicolumn{2}{|c|}{ Total area of Constantine city } & 90.1 \\
\hline
\end{tabular}

Statistical analysis of the areas observed shows that more than $50 \%$ of the study area is highly vulnerable. This alarming situation requires a range of actions to be implemented to ensure an effective response

The robustness and reliability of the process is also based on the adequacy of the aptitude criteria chosen for each parameter, the weighting adopted, but also the quality of the spatial information that has been exploited (Kedowide Mevo Guezo, 2011, p. 138).

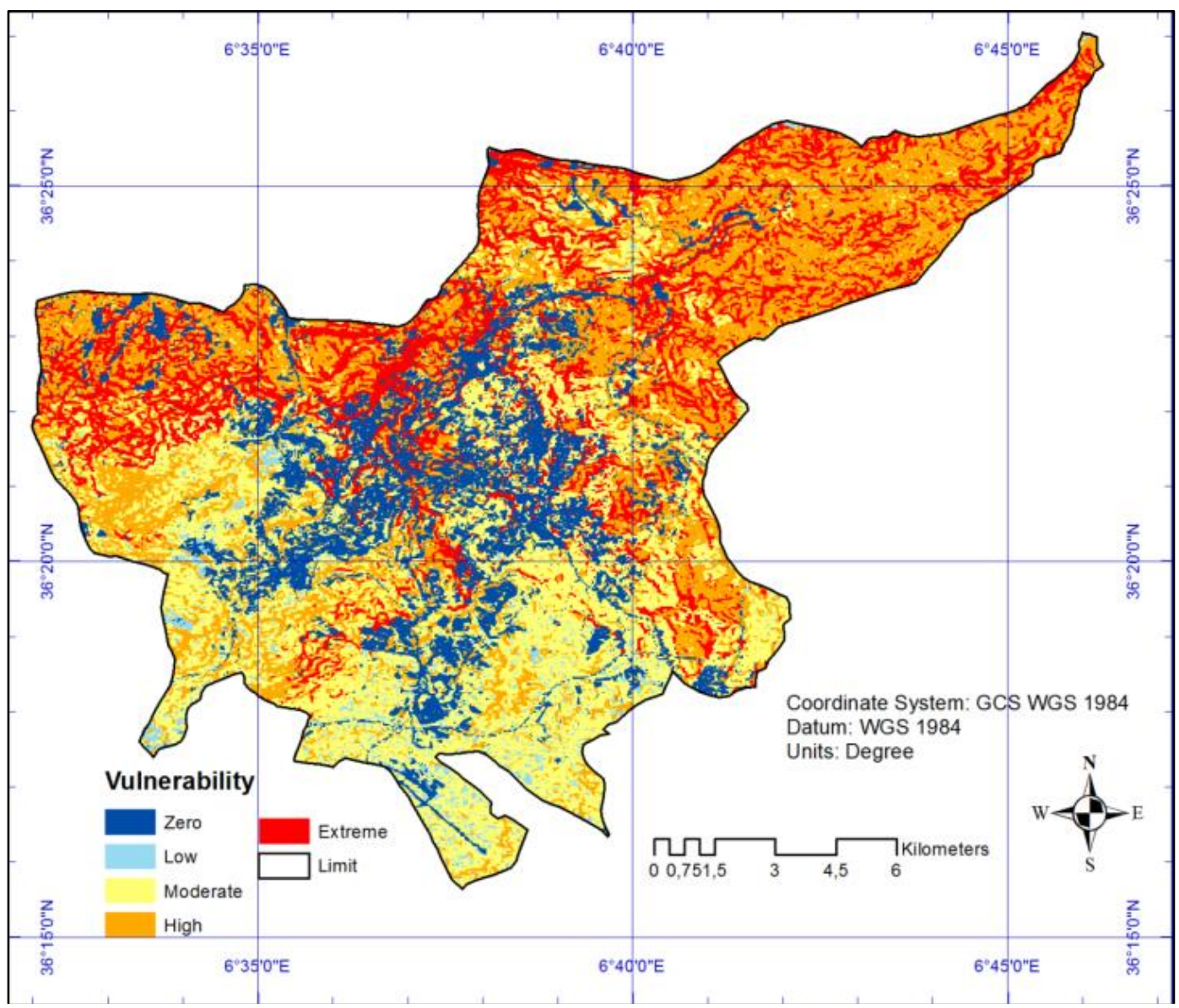

Figure 4. Vulnerability map 


\section{CONCLUSION}

The erosion vulnerability assessment was made by a multi-criteria analysis Weighted Linear Combination (WLC) that represents reliability according to several authors.

A large area of the city has been identified as a significant vulnerability given the meeting and the significant interactive influence of factors contributing to the erosion process, in particular the slope and Rainfall.

Based on this study, decision makers may have high vulnerability mapping and facilitate the intervention and implement erosion control measures although there are a number of limitations to this approach.

\section{REFERENCES}

Bouguerra, S., \& Bouanani, A. (2016). Qualitative mapping of soil sensitivity to water erosion: Case of the Oued Boukiou watershed (north west of Algeria). Étude et Gestion des Sols, 23, 91-100.

Chakhar, S. (2006). Cartographie décisionnelle multicritère: formalisation et implémentation informatique (Doctoral dissertation).

Toundoh. O.P., Tchibozo, E.A.M., Vissin, E.W. (2020). Application Du Modèle empirique USPED À L'étude De L'érosion hydrique Dans Le Bassin De La Yéwa Au Bénin. International Journal of Engineering Science Invention (IJESI), 9(1), 67-78.

Kedowide Mevo Guezo, C. G. (2011). SIG et analyse multicritère pour l'aide à la décision en agriculture urbaine dans les pays en développement, cas de Ouagadougou au Burkina Faso (Doctoral dissertation, Paris 8).

FAO, (1980). Conservation des ressources naturelles en zone arides et semi-arides. Cahiers FAO: conservation des sols 3. p. 135.

Herman, G.V., Gaceu, O., Mester, C., Baias, S., Caciora, T. Wendt, J. A. (2019). Spatial Analysis of Water Quality in Natura 2000 Sites Bihor, Romania. Journal of Environmental Protection and Ecology, 20(4), 2121-2129.

Romocea, T., Oneț, A., Sabău, N.C., Oneț, C., Herman, G.V., \& Pantea, E. (2018). Change of the groundwater quality from industrial area Oradea, Romania, using Geographic Information Systems (GIS). Environmental Engineering \& Management Journal (EEMJ), 17(9), 2189-2199.

Malczewski, J. (2004). GIS-based land-use suitability analysis: a critical overview. Progress in planning, 62(1), 3-65. doi:10.1016/j.progress.2003.09.002

Balzarini, R., Davoine, P.A., Ney, M. (2013). Analyse comparée des stratégies 'experts vs étudiants lorsde la réalisation de cartes de susceptibilité. CFC $\left(\mathrm{N}^{\circ} 218\right.$ - Décembre 2013).

Steffan, V. (2016). Manuel d'utilisation de MCDA4ArcMap, version 1.1 A. Created on Wednesday, February 24.

Wischmeier, W. H., \& Smith, D. D. (1978). Predicting rainfall erosion losses: a guide to conservation planning (No. 537). Department of Agriculture, Science and Education Administration.

Saini, S. S., Jangra, R., \& Kaushik, S. P. (2015). Vulnerability assessment of soil erosion using geospatial techniques-A pilot study of upper catchment of Markanda river. International Journal of Advancement in Remote Sensing, GIS and Geography, 2(1), 9-21.

Submitted:

May 12, 2019
Revised:

Aprile 07, 2020
Accepted and published online

July 28, 2020 